\title{
'Should I Ignore the Promotion System and Stay or I Should Quit': An Examination of the Experiences of Teachers with the Promotion Process in the Ghana Education Service
}

\author{
Vincent de Paul Kanwetuu ${ }^{1}$, Joseph Asomaning Brenyah ${ }^{2}$, Bernard Obeng ${ }^{1}$ \\ ${ }^{1}$ Department of Sociology and Social Work, Faculty of Social Sciences, Kwame Nkrumah University of Science and \\ Technology, Ghana \\ ${ }^{2}$ PhD Candidate: Department of Sociology and Social Work, Faculty of Social Sciences, Kwame Nkrumah University of \\ Science and Technology, Ghana
}

Correspondence: Vincent de Paul Kanwetuu, Department of Sociology and Social Work, Faculty of Social Sciences, Kwame Nkrumah University of Science and Technology, Ghana.

\author{
Received: February 13, 2020 \\ Accepted: April 10, $2020 \quad$ Available online: April 23, 2020 \\ doi:10.11114/ijsss.v8i3.4718 \\ URL: https://doi.org/10.11114/ijsss.v8i3.4718
}

\begin{abstract}
Promotion is a key determinant of employee advancement on the organizational ladder. However, in the Ghana Education Service, there are several reports of irregularities in the process which make the promotion less of a merit-based mechanism. The purpose of this study, therefore, was to examine teachers' perception of fairness in the promotion process and how that affects their willingness to stay in the Service and teach effectively. Using a descriptive survey involving both close-ended and open-ended questions, the opinions and experiences of 342 randomly sampled teachers in the Ejisu-Juaben Municipality were examined using correlations and binary logistic regressions as well as thematic analysis. The results show that fairness in the promotion process was a significant contributor to teacher retention and effective teaching. However, the process is tainted with favoritism and partiality. Governments should, therefore, not be interested in incentivization only as a retention strategy but also come out with strategies aimed at ensuring transparency in the promotion process to make it a performance-based mechanism that sieves and preserves best talents.
\end{abstract}

Keywords: promotion, retention, attrition, Ghana, equity, Ghana education service

\section{Introduction}

All over the world, education is recognized as a key component for effective development (The Schwab Foundation, 2017). The essence of education at any level, therefore, cannot be underestimated. This is because education presents the basis for the development of the human resource of any country which in turn drives the effective utilization of the natural and material resources for development (Asare and Nti, 2014).

Access to quality classroom education is one of the sustainable development goals set by the United Nations for its member countries (SDG4) for the next fifteen years (Derek Osborn, 2015). In line with international best practice, Ghana has subscribed to this goal among others and is making frantic efforts to increase access and quality to formal education for all by the year 2030. But access to quality education requires a motivated and stable teacher in adequate numbers with regard to the number of learners. As part of its educational objective in relation to the sustainable development goal No.4 (SDG\$), Ghana is implementing free education for all her citizens up to secondary school level (National Development Planning Commission, 2015). This is to attain equal access for all students irrespective of their financial background (Government of Ghana, 2008). What remains a challenge now is the quest for quality. The significance of the teacher at this level cannot be overemphasized. It is the teacher who builds the foundation for further and higher learning. This must take place at the pre-tertiary level where the teacher is the hub around which access and quality meet. It is for this reason that all efforts must be put in place to obtain adequate and stable, well-motivated teachers to be able to build strong educational foundations in pupils and students at the pre-tertiary levels.

The Government of Ghana has, therefore, over the years, increased the number of teacher training colleges to train and develop teachers to form the foundation for training the manpower needs of the nation (Asare and Nti, 2014). Yet, the 
Ghana Education Service has been facing problem of teacher attrition. The Ministry of Education, through the Ghana Education Service (GES), has put in place some incentives packages to retain teachers. Some of these packages include faster promotion and study leave with pay for teachers posted to deprived rural areas, the annual best teacher award scheme (Yeboah, 2012), with the aim of attracting and retaining teachers (Brown, Donkoh and Eyiah-Wilson, 2013) in the classroom. Yet the problem of teacher attrition persists. This problem has attracted the attention of several educationists, governments and researchers with the aim of unraveling the real causes of teacher attrition.

For instance, (Osei Akuoko, Dwumah and Mahama Baba, 2012; Sinha, 2012; Aziz, 2013) attributed the cause to poor salaries and benefits. Yet some other researchers found a relationship between attrition and compensation (Turnley and Feldman, 2000), attrition and employee motivation (Chris, 2009), attrition and job satisfaction (Boomer Authority, 2010) and conditions of service (Sam and Effah, 2014). These studies imply that effective reward systems account for stable and motivated teachers in the classroom. It also means that the reward system within the Ghana Education Service is apparently weak and for that matter teachers continue to quit for better conditions of service elsewhere. Yet, there is scientific evidence supporting the fact that the strength of an educational system depends on recruiting and retaining good teachers (OECD, 2011).

Even though there is enough evidence in support of teacher attrition in the Ghana Education Service due to poor remunerations, there is also ample evidence of bottlenecks, delay and unfairness in the promotion of teachers within the service. For instance, Danku et al., (2015) found that the appraisal process which leads to recommendations for promotion was mostly used to victimize teachers. Thus, only $20 \%$ perceived the appraisal process to be fair as against $80 \%$ who experienced unfair dealings with their supervisors. Other studies also indicate that the promotion process is bedeviled with cumbersome bureaucratic procedures and unethical conduct of promotion interview panelists with biased considerations for older teachers thus making the process less of a merit-based mechanism. Many teachers, especially the younger ones, therefore, refuse to apply for promotions but rather prefer study leave with pay in order to develop themselves and quit the GES (Adam and Boakye, 2016; Kombat, 2017). When one finally goes through such hurdles in the promotion process successfully, the next problem faced is delay in putting one on the right salary scale According to a president of the National Association of Graduate Teachers in the GES, the procedures in the GES are characterized by delay in the release of promotion letters, delay in placement of promoted teachers to the right scales sometimes up to five years whereas their counterparts in other public sectors will be enjoying their right rank and scale. These delays sometimes lead to denial of salary arrears and consequent strikes and dissatisfaction (Sambou, 2019).

From the discussion so far, one would see that the promotion process is characterized by delay and procedural unfairness. However, studies so far have focused on teacher rewards as explanation for attrition to the near neglect of teacher promotion. While all of the factors in the literature so far can be categorized as motivational deficit, what is seemingly missing is the link between opportunities for growth or career development and employee retention in the Ghana Education Service. In other words, there is an apparent gap in literature on the relationship between promotion as an interactional process and teacher attrition. This paper, therefore, promises to fill the apparent gap in literature by arguing that a fair, transparent and equitable promotion process can serve as significant strategy for teacher retention in addition to satisfactory rewards. In other words, salaries and conditions of service are important components of employee retention but to a large extent, those factors are dependent on an individual's rank or position within the organizational structure. Since position or rank and rewards are also determined by the promotion process, it is pertinent to systematically examine this process in addition to its outcomes in order to make recommendations for holistic improvement in retention efforts under the GES (Pergamit and Veum, 2016). In this regard, the paper seeks to specifically answer the following questions:

1. How do teachers in the Ghana Education Service perceive the promotion process?

2. What is the level of satisfaction of teachers with the promotion outcomes?

3. To what extent does perception of fairness in the promotion process affect teacher retention and attrition?

4. Would a perceived fair process affect effective teaching?

\subsection{Study Area}

The Ejisu-Juaben Municipal Assembly is one of the 43 Metropolitan, Municipal and District Assemblies (MMDAs) in the Ashanti Region of Ghana with Ejisu as its administrative capital. The Municipality is known for its rich cultural heritage and tourists' attractions notably the Kente (a traditional cloth in Southern Ghana) weaving industry. The Municipality stretches over an area of $637.2 \mathrm{~km} 2$ constituting about $10 \%$ of the entire Ashanti Region. The Ejisu-Juaben Municipality is located within longitudes $1^{\circ} 5 \mathrm{~W}$ and $1^{\circ} 39^{\prime} \mathrm{W}$ and latitudes $7^{\circ} 9^{\prime} \mathrm{N}$ and $7^{\circ} 36^{\prime} \mathrm{N}$. It shares boundaries with six (6) other Districts in the Region. To the north-east and north-west of the Municipality are Sekyere East District and Kwabre East Municipal respectively, to the south are Bosomtwe District and Asante Akim South 
Municipal, to the east is the Asante Akim North Municipal and to the west is the Kumasi Metropolitan Assembly. According to the 2010 Population and Housing Census, the Municipality has a population of 143,762 inhabitants; out of which 68,648 are males and 75,114 are females. The educational affairs of the Municipality is under the auspices of a District Directorate that has a total of 271 educational institutions comprising 92 kindergarten (KG) schools, 95 primary schools, 77 junior high schools (JHS), 5 senior high schools (SHS) and 2 technical and vocational education and training (TVET) schools. The directorate has a total of 2, 316 teachers distributed across the 271 educational institutions (Ghana Education Service, 2016) in the Municipality.

\section{Literature Review}

\subsection{Criteria for the Promotion of Teachers in Ghana Education Service}

The Ghana Education Service has two categories of teachers. The first category is those who have been trained and certified as professional teachers with education as a specialized area while the second category are those who have not been trained as professional teachers and therefore possess only academic qualifications without any specialization in education. The promotion criteria for these two categories of teachers are different (Adam et al., 2016)

Non-professional teachers who do not have academic qualifications up to Diploma and above do not go on promotion at all. Such teachers remain at the status at which they were employed and therefore do not have any opportunity to progress on the organizational structure in the Ghana Education Service. Non-professional teachers who have qualification up to a diploma and beyond go on promotion but terminate at the rank of a deputy director of education after which they cannot go further (United States Agency for International Development, 2012)

All professional teachers on the other hand have a privilege to go on promotion but with different terminating points based on one's professional and academic qualification. Professional teachers who do not have diploma in education terminate promotion at the level of Assistant Director 1 while those with diplomas terminate their promotion at the level of a Deputy Director of Education. However, professional teachers with first degree and beyond can go on promotion up to the rank of a Director General of the service (United States Agency for International Development, 2012).

Progression through the ranks of the Ghana Education Service is dependent on both qualification and length of service. In relation to length of service, even though it is not explicitly stated as a condition for promotion, one can only be promoted to the next rank when one has served on one's current rank for a minimum of three years. This implies that the longer a person stays in the service the greater the opportunity to rise up the organizational ladder (Adam et al., 2016), all things being equal. With regard to academic and professional qualifications, there are different starting as well as terminating points for various categories of teachers. While non-professional graduate teachers automatically start on the rank of principal superintendent and terminate at the rank of a deputy director, professional graduate teachers start on the rank of principal superintendent and can rise as far as director general. In the same vein certificate ' $A$ ' teachers start on the rank of Superintendent I and automatically terminate at the rank of Assistant Director 'I' even though they are professionally trained teachers. In addition, professional teachers with Diploma qualification start on the rank of Senior Superintendent 'II 'and terminate at the rank of a Deputy Director. This implies that the higher a teacher's professional and academic qualification, the greater the possibility for the teacher to rise up the organizational ladder.

\subsection{The Promotion Process in Ghana Education Service}

In the Ghana Education Service, there are two major processes of promotion permitted by policy. Teachers from the rank of Superintendent 'II' up to the Senior Superintendent 'I' are promoted on the basis of inspection of work. Superior officers within the service inspect the work output of such teachers when they are due for promotion. Based on the work output of the teacher, recommendations are made to the Ghana Education Service Council for the promotion or not of such a teacher.

On the other hand, teachers who aspire for the rank of Principal Superintendent and beyond go through an interview process when they are due for promotion. The Ghana Education Service Council mandates senior officers both active and retired within the service to set up interview panel at the regional directorates of education to interview and assess teachers due for promotion for the rank of Principal Superintendent and above based on which recommendations are made to the Council for the promotion of such teachers or not.

\subsection{Teacher Professionalism in Ghana}

The first teacher training college was built and started in the Gold Coast (now Ghana) by the Basel Mission in 1848 . Later, other missions (churches) emulated their example to train teachers for their mission schools(Owusu-Agyakwa, Ackah and Kwamena-Poh, 1993). Since then, teacher training and development in Ghana has witnessed changes in structure and content motivated by changing needs of the Ghanaian society and globalization.

For instance, in the 1930s, there was the four-year Cert 'A' training for middle school leavers to teach in primary and 
middle schools. This era attracted the best brains in terms of qualification since the teaching profession then was deemed very honorable. This was followed by the two-year Cert 'B' for post-middle school leavers in response to rapid expansion in access to primary and middle school education in 1937. By 1951, due to further expansion under the Accelerated Development Plan, there was the introduction of Post 'B' Cert "A" to upgrade Post B teachers who have been in the field for some time. The number of teacher training colleges increased from 20 to 30 by 1957. At the same time, there was the introduction of a two-year Cert ' $\mathrm{A}$ ' for those secondary school leavers to go back and teach in both middle and secondary schools. This was to also cater for the expansion in access to secondary education resulting from the Accelerated Development Plan at the time. There was also the introduction of the two-year teacher training on specialist areas such as home science, physical education, music, etc. open to all existing teachers. This later transformed to a three-year diploma awarding programme(Department for International Development, 2003).

In 1987, all the above programmes were phased out and replaced with three-year post-secondary Cert 'A' with the aim of improving teacher professionalism(Department for International Development, 2003). These changes were occasioned by the Dzobo Committee of 1972. The committee was appointed by government to examine the structure and content of education in Ghana with the aim of making education more context relevant. After two years, the Committee came out with its recommendations in 1974. There was the need for a revamp in the structure and content of the education system in Ghana. The Junior Secondary School (JSS) system was proposed to replace the Middle School Leaving Certificate (MSLC) system. However, the government had no sufficient funds to implement the recommendations until 1987 when IMF and World Bank conditionality forced the government to implement it under the educational reforms programme. The aims of the JSS system included increased access at all levels, expansion and equity; improving educational infrastructure and pedagogy. The others were an expansion in curricula to include academic, cultural, technical and vocational training; a reduction in the length of pre-university education from 17 to 12 thereby reducing cost (Benneh, 2001).

These reforms brought structural and curricula changes to teacher education in the country. In terms of structure, a four-year Cert. 'A' was introduced for teachers with MSLC and three-year Cert. 'A' for teachers with post-secondary qualification. With regard to curriculum, technical and vocational subjects were introduced and the training colleges (then 38 in number) were classified into two with specialization in either science (group 1 colleges) or arts (group 2 colleges) (Asare-danso, 2014)

Around the year 2000, there were public concerns about too many subjects being studied in basic schools. The Government of Ghana responded by setting up the Anamuah-Mensah Committee in January 2002 to review the pre-school, basic, secondary, technical, vocational, teacher and tertiary education to make them more responsive to the needs of the country. Recommendations made for teacher education included upgrading from certificate awarding institutions to diploma awarding institutions with name change from Teacher Training Colleges to Colleges of Education. Teachers teaching with Cert. ' $\mathrm{A}$ ' were required to do top-up programmes during weekends and holidays to upgrade to diploma. Provisions were also made to enable untrained teachers acquire diploma in basic education by distance programmes (Asare and Nti, 2014).

It is, however, pertinent to note that teacher training in Ghana is not able to attract academic candidates with strong grades as most applicants are re-sit candidates. This has negative implication for prospective teachers' ability to assist learners develop deep conceptual understanding of subjects taught (Department for International Development, 2003). Currently, the colleges of education produce diploma teachers whereas the education related tertiary institutions produce both diploma and first degree (B. Ed.) teachers.

\subsection{Promotion as Determinant of Employee Retention}

Research reports indicate that there is positive correlation between promotion and job satisfaction (Mustapha and Zakaria, 2013) and that job satisfaction in turn promotes employee retention (Kossivi, Xu and Kalgora, 2016). Even though several factors could account for employee retention or attrition such as managerial leadership, compensation, remuneration and job satisfaction, most employees' decision to stay in an organisation is based on career development which includes opportunities for promotion and complementary benefits such as salary raise, autonomy, responsibility and recognition (Horwitz, Heng and Quazi, 2003; Arnold, 2005; Rolfe, 2005). Oyaro (2010) found that delay in promotion among teachers led to stagnation which negatively affected teachers' job satisfaction and enhancement. Kunyiha et al., (2016) also found that slots allocated by governments for the promotion of teachers in developing countries especially Africa are relatively smaller when compared to the number of teachers who are due for promotion. This is partly due to the inability of the governments, who are the major employers, to pay for remuneration associated with promotions. Hence the selection procedures restrict itself to promoting teachers compelling a lot of them to remain in the same rank for a number of years even though they duly qualify to be promoted (Kunyiha et al., 2016).This is a disincentive to teachers and an impetus for attrition at the least opportunity but the study did not test the relationship 
between promotion and attrition.

Kunyiha et al., (2016) further identified the influence of human resource practices on teacher commitment in developing countries. Promotional opportunities are essential for teacher commitment where effective appraisal by educational authorities is used as basis for promotion. Furthermore, about $45 \%$ of respondents agreed that promotion leads to increases in pay, but above all, they regard promotion as an avenue for career advancement and the achievement of personal goals and job satisfaction. A case in point whereby teachers' promotion was delayed in a developing country due to government's inability to pay is Mugweru's 2013 study in Kenya. Mugweru (2013) noted that a lot of teachers continue to remain in one category notwithstanding the outlined processes and procedures for promotion which include academic qualification, duration of service and performance on the job. This, invariably, affects their morale compelling them to seek other avenues for professional advancement and the achievement of personal life goals.

The study (ibid.) identified delay in the release of interview results, lack of feedback to teachers who qualify for promotion but were not shortlisted as well as those who failed promotion interviews and the generality of questions asked beyond the teacher's area of specialization as sources of de-motivation to teachers. This study, however, did not examine the effect of promotion on teacher retention or attrition.

The study (Mugweru, 2013) further indicated that disparity in work environments are not considered during promotion even though environmental conditions contribute to the performance of both teachers and students which is a major criterion for promotion. Ogonda et al., (2015), however, did not consider school environmental differentials as a contributory factor to the success or otherwise of teacher promotion.

In a survey on the status of teachers and the teaching profession in China (Education International, 2015) it was found that among major factors that determine the status of teachers and the teaching profession, promotion plays a key role as it determines the salary and working conditions of teachers which has a direct link with the status of teachers. Unfortunately, findings from this survey indicate that working conditions of teachers have declined over the years and that even though the numbers of teachers have been increasing in recent times, their working conditions are worst off when compared with professionals of similar or same qualifications in other public sector agencies.

Bennell and Acheampong (2007) noted that promotion of teachers should be made transparent if it were to achieve desired results. They further argue that differences in rewards between different grades in promotion should be wide enough to entice teachers to want to get promoted. This study focused on making the promotion and its process attractive and transparent respectively but did not also determine the relationship between the promotion process and teacher attrition or retention. The current study is therefore, intended to fill this gap by testing the relationship between procedural fairness and teacher attrition or retention when it comes to promotion in the GES. The aim is to contribute to knowledge on the significance of the promotion process as a retention mechanism.

\subsection{Theoretical Framework}

An examination of fairness in the promotion process and its effect on satisfaction with outcomes and teacher retention or attrition will be better explained using a process theory. Whereas content theories of motivation focus on incentives as sources of motivation for employees to work and stay in organizations, process theories focus on procedures and interrelationships leading to both intrinsic and extrinsic rewards. In view of the above, the theoretical framework for this study is anchored on two process theories which will complement each other in explaining how the promotion process can lead to retention or attrition of teachers. they include the expectancy theory (Vroom, 1964) and equity theory (Adams, 1963, 1965). According to expectancy theory, there are three related factors that bring about employee motivation. These are expectancy, instrumentality and valence. If a teacher is hard working, he/she should believe that he/she will meet targets set for him by his employer. This belief is called expectancy. It is simply a belief in the ability to achieve a set objective (performance standard) with the exhibition of appropriate effort. Once that performance is achieved, the teacher should also believe that his performance will yield a certain outcome. This performance outcome linkage is called instrumentality. For instance, a teacher who works hard and satisfies all criteria for promotion within a specified period of time expects to be promoted. Finally, the outcome must be valuable to the teacher if he/she is to be motivated to work hard or stay in the organization. In other words, the rank and rewards associated with the promotion should be cherished by the teacher.

Even though Vroom (1964) and Porter and Lawler (1968) first applied the theory to explain motivation in organization, expectancy theory has been used to explain a variety of situations in organization. For instance, Mobley and Meglino (1977) applied expectancy theory in the study of competitive behaviour, Frank and Lewis (2004) applied it to study pay for performance, and budget allocation (Monge, Cozzens and Contractor, 1992). This study seeks to use the theory to explain how fairness in the promotion process affects teacher retention. 
According to Lunenburg (2011), Vroom's expectancy theory has four assumptions. First, people join organizations expecting that their needs will be met. This assumption tells of how the individual will behave or what level of effort they will exhibit when they join the organization. Second, an individual's performance is the result of conscious effort. This means that the individual can choose not to work or not to work hard. Third, people want different outcomes from the organization such as salary, bonuses, allowances, profit, job security, promotion (advancement, growth) or challenge. Finally, people will choose from among alternatives to maximize their needs.

Although expectancy theory has been used by many scholars and researchers to study behaviour in organizations, it is unable to account for circumstances where there is uncertainty (Wahba and House, 1974). For instance, how will an employee assess that a certain effort will yield a certain performance standard, that a certain performance standard will yield a certain outcome and that the certain outcome will be valuable to the individual? The theory again suggests that the relationship between expectancy, instrumentality and valence is multiplicative, i.e. motivation = expectancy $\mathrm{x}$ instrumentality $x$ valence (Lambright, 2010). This means that an individual must have all three in order to be motivated. It also implies that all three must be high to bring about high motivation and consequently when one or two or all three are low, motivation will also be low. However, studies have shown that there are empirical relationships other than multiplicative only (Lambright, 2010).

To complement and give support to the weakness of the expectancy theory in explaining motivation of teachers to stay in GES, this study uses the equity theory (Adams, 1963, 1965) as additional theoretical framework. This theory postulates that a worker compares his or her input-outcome ratio to that of a referent other. If the worker finds himself or herself in an inequitable situation, such a worker will indulge in behaviour that will yield him/her equity. Therefore, teachers will compare their inputs and outcomes with those of colleague teachers during and after promotion. If they find out that they have been treated unfairly compared with others, the victim (in this case) can choose to reduce input; in which case demotivation to work sets in. They could also be demonstration or strike, or attrition (leave the job entirely).

According to Huseman, Hatfield and Miles (1987), there are four propositions that capture the objectives of equity theory. First, individuals evaluate their relationship with others by comparing their input-outcome ratio with those of others. Second, inequity exists when the ratios of the individual and the referent other are unequal. This is the beginning of feeling of dissatisfaction and demotivation. Third, the greater the perception of inequity, the more distressed the individual becomes. Finally, the greater the distress the more the individual will work to restore equity and reduce the distress which include quitting the job especially if the intention to quit is there or if there are alternative jobs (Al-zawahreh and Madi, 2012). This theory is therefore, appropriate in finding out how teachers will behave in the GES if they find out that they have been treated inequitably in the promotion process.

In deciding whether to leave or not, the Expectancy and Equity Theories have been useful. According to the expectancy theory, a teacher judges whether a specific behaviour would result in an expected outcome (primary result), whether a primary result will account for a secondary result or outcome, and whether the secondary outcome is relatively attractive to him or her (NěmeČková, 2017). This judgement is based on perception. For that matter expectancy, instrumentality and valence linkage is first of all a cognitive process with futuristic assumptions of certainty of results in all three components of the theory. The equity theory, on the other hand, is retrospective in nature, and which does not use assumed certainty but rather perception of factual results. This means that a teacher is only able to do the referent other comparison after going through the promotion process and after receiving outcomes following the process, he or she uses that to compare with colleagues. Thus, there is an emphasis on the reward to be obtained as a teacher (thus, promotion) and how fair the promotion process is (Hatfield, Salmon and Rapson, 2011). Here, a teacher compares his or her efforts and outcomes to that of other teachers in order to determine whether the promotion process as well as the outcome, was fair. When a teacher establishes that promotion was not on an equitable basis, he or she is likely to leave the teaching profession (Watson et al., 2006), since there is experience of internal inequity (Hatfield, Salmon and Rapson, 2011). On the other hand, teachers are more likely to stay when they perceive the system of promotion to be fair and equitable. As such, there is the higher tendency that a teacher would stay if he or she feels that the promotion they receive is commensurate with their efforts (Asni and Sulong, 2018).

\section{Research Design and Methods}

The study is intended to examine opinions of fairness and satisfaction with the promotion process and outcomes respectively among teachers in one municipality in Ghana. It also aimed at examining the relationship between promotion and retention of teachers. The study is therefore a quantitative in approach since the main objective is to find relationships between variables for the purposes of generalization. It is designed as a cross sectional survey of teachers at all levels in the Ejisu-Juabeng Municipality in the Ashanti Region of Ghana. In other words, participants were drawn from preschool centres, primary, junior high, senior high, technical and vocational training schools. The total teacher 
population is 2, 316. The Municipality has total of 271 educational institutions comprising 92 kindergarten (KG) schools, 95 primary schools, 77 junior high schools (JHS), 5 senior high schools (SHS) and 2 technical and vocational education and training (TVET) schools. There were 2, 316 teachers distributed among the 271 educational institutions (Ghana Education Service, 2016) in the Municipality.

The teacher population was, however, made up of both trained (professional) teachers and untrained ones (pupil teachers). They also included both male and female teachers of varying ages and qualifications. Their opinions and experiences were sought for in the areas of promotion interviews and the promotion outcomes in terms of ranking and accompanying rewards.

The sample size was determined based on Miaoulis, G. \& Michener (1976) five criteria of determining an optimum sample size; thus, the purpose of the study, the size of the population, the degree of variability in the attribute being measured, the level of precision and the level of confidence. The purpose of the study was to examine the promotion process and the role it plays in teacher retention. The teacher population in the study area was found to be 2,316 . The attribute being measured among the population was teacher promotion which has fixed variability among professionally trained teachers based on entry qualification and number of years of service. For untrained teachers, there was no variability in promotion since the policy of the service did not provide for promotion among pupil teachers unless they obtained a certificate in education.

With an allowance of 5 percent margin of error and 95 percent confidence level, the sample size was computed using (Yamane, 1967) formula for a definite population as follows: $\mathrm{n}=\frac{N}{1+N(e)^{2}}$; where $\mathrm{n}=$ sample size, $\mathrm{N}=$ population size, $\mathrm{e}$ $=$ level of precision (estimated as .05), and $1=$ constant. Substituting the values into the formula, $\mathrm{n}=\frac{2316}{1+2316(.05)^{2}}$; a sample of 342 was obtained.

The proportional random sampling technique was employed to select the respondents for the study using a sampling frame obtained from the Planning and Statistics Department of the Municipal Education Office (2016). Consequently, the sample size (342) was made up of 31 untrained teachers and 311 trained teachers. They were then administered with a survey questionnaire involving items on the Likert type scale where the respondents were required to rank their opinions or experiences. Explanations to those opinions ranked were sought for using follow-up open-ended questions. Open-ended questions were preferred to face-to-face interviews because it increased anonymity of respondents and thus, took away the fear of possible victimization especially when they had to say something true but unpleasant about their experiences with officers in the promotion process. However, this paper admits as a shortcoming the inability to incorporate non-verbal cues accompanying responses to the open questions which would otherwise be taken care of by personal interviews. Secondly, the survey was not national in scope due to financial constraints encountered by the researchers. Therefore, the findings may not be nationally representative since the respondents were sampled from one municipal assembly. However, to the extent that the survey is representative of the population of teachers in the study area, the findings are useful as a starting point for review of policy and practice regarding teacher promotion and retention strategies for the nation as a whole where pecuniary benefits have been found to be inadequate compared with other sectors.

The responses to the Likert-type items in the questionnaires were analyzed using descriptive statistics involving the mode and the median. Relationships between and among variables were computed using Pearson correlations with the aim of determining both the direction and strength of the relationships. The Binary Logistic Regression was used to determine the impact of promotion on teacher retention or attrition for that matter. The variables in the equation included teacher promotion, fairness of the promotion process, satisfaction with rank and rewards, internal and external equity. Written responses to the open-ended questions were analyzed thematically and used to buttress the survey responses.

\section{Results}

\subsection{Demographic Characteristics of Respondents}

The background information which was deemed necessary for analysis included the sex, age, academic qualification, and the professional status of the respondents. These characteristics are possible sources of variations in respondents' perceptions and experiences regarding teacher promotion, ranking and rewards administration. 
Table 1. Demographic characteristics of respondents

\begin{tabular}{lccc}
\hline Variable & Categories & Frequency & Percent \\
\hline \multirow{3}{*}{ Sex } & Male & 233 & 68.1 \\
& Female & 109 & 31.9 \\
\hline \multirow{4}{*}{ Age } & Total & $\mathbf{3 4 2}$ & $\mathbf{1 0 0 . 0}$ \\
& Below 30 & 51 & 14.9 \\
& $30-39$ & 222 & 64.9 \\
& $40-49$ & 68 & 18.4 \\
& $50-59$ & 6 & 1.8 \\
Academic qualification & Total & $\mathbf{3 4 2}$ & $\mathbf{1 0 0 . 0}$ \\
& Secondary Education & 19 & 5.6 \\
& Diploma & 16 & 4.7 \\
& Degree & 222 & 64.9 \\
& Higher Degree & 85 & 24.9 \\
Professionalism & Total & $\mathbf{3 4 2}$ & $\mathbf{1 0 0 . 0}$ \\
& Trained & 311 & 90.9 \\
& Untrained & 31 & 9.1 \\
& Total & $\mathbf{3 4 2}$ & $\mathbf{1 0 0 . 0}$ \\
\hline
\end{tabular}

Source: Field Survey, 2019.

Regarding sex distribution of the respondents, $68.3 \%$ of them were males compared to $31.7 \%$ females. Thus, the majority of the respondents were male. This implies that the analysis and opinions expressed here are male dominated.

The age distribution of the respondents shows that people within the age group of 30-39 years were the majority with $65.7 \%$. The least age group was $50-59$ years with $1.7 \%$, and the youngest category of respondents (below 30 years) was $14.8 \%$. The rest were $40-49$ years representing $17.8 \%$ of the sample. This result indicates that the district has a youthful teacher population, which also implies that they could be energetic and ambitious as far as work is concerned. They may, however, need a lot of in-service training since they are young and lack sufficient work experience. In every profession, academic qualification remains an important determinant of promotion and rewards administration. The results of the study show that the majority (64.3\%) of the respondents were graduates with first degree and $25.2 \%$ with master's degree. The rest were $4.8 \%$ diploma holders and 5.7\% secondary school leavers. Put together, $89.5 \%$ of the respondents have had university education, which is an indication that academic qualification was generally high among the respondents. Hence, they would generally be expecting high rewards in terms of positions, allowances and salaries. Since teaching is a profession, it was important to find out, apart from the level of academic qualifications, how many of them were specifically trained as teachers for the job. This is because one could have a university degree but not with education and methodology of teaching students. From Table 1, an over whelming majority of the respondent (90.9\%) were professionally trained while only $9.1 \%$ were untrained, i.e. pupil teaching. Whereas a lot of coaching and close supervision is required for a few of the respondents (i.e. the pupil teachers), the district is assured of professional delivery from majority of its teachers.

\subsection{Having Been Promoted or Not}

An objective of the study was to find out the percentage of teachers who have had promotion and assess their level of satisfaction with the process as well as the outcome. From Table 2, it is clear that a large majority (77.5\%) of the respondents have been promoted at least once since their appointment into the Ghana Education Service.

Table 2. Having being promoted or not

\begin{tabular}{lcc}
\hline Response & Frequency & Percent \\
\hline Yes & 265 & 77.5 \\
No & 77 & 22.5 \\
\hline Total & 342 & 100.0 \\
\hline
\end{tabular}

Source: Field Survey, 2017

This also implies that the opinions expressed in this paper regarding promotions and reward administration represent $77.4 \%$ of the respondents talking from experience.

The teachers who have never gone on promotion $(22.5 \%)$ gave varied reasons. Some said they were not professional 
teachers and for that matter would never qualify for promotion as prescribed by policy in the Ghana Education Service. For some others, they had not gone on promotion because per the conditions of service of the Ghana Education Service, they were not due for promotion. For another category they had not gone on promotion because the process was too cumbersome and as compared with the promotion outcomes it was not worthwhile going on promotion

\subsection{Descriptive Statistics}

On a scale of 1 to 5 representing the degree of fairness and satisfaction, the respondents ranked their opinions on how fair and satisfactory the promotion process and the rewards were, respectively. On the scale, 1 represents very unfair or very dissatisfactory and 5 represents very fair or very satisfactory. The number 3 represents neutral, meaning a respondent is indifferent to the item under consideration. Regarding the perception of fairness with the promotion process, the mean response was 2.5 with a standard deviation of 1.2. This meant that the respondents generally perceived the promotion exercise to be unfair or they could not tell whether it was fair or not.

It was a similar situation with regards to external equity in promotions. In other words, the average response was 2.1 with a standard deviation of 1.4. However, satisfaction with rank, rewards and internal equity slightly improved over fairness of the promotion exercise and external equity. For instance, in terms of satisfaction with rank, the mean response was 2.6 with standard deviation of 1.1, that of satisfaction with rewards was 2.5 with a standard deviation of 1.1 and finally, internal equity scored an average of 2.8 with standard deviation of 1.3 .

Table 3. Descriptive statistics

\begin{tabular}{lrrrrr}
\hline Variables & N & Min. Max. Mean SD. \\
\hline Perception of fairness of the promotion exercise & 342 & 1.00 & 5.00 & 2.5 & 1.2 \\
\hline Satisfaction with ranks attached to promotions & 342 & 1.00 & 5.00 & 2.6 & 1.1 \\
\hline Satisfaction with rewards attached to promotion & 342 & 1.00 & 5.00 & 2.5 & 1.1 \\
\hline Internal equity in promotions (in Ghana Education Service) & 342 & 1.00 & 5.00 & 2.8 & 1.3 \\
\hline External equity in promotions (Compared with other public sector workers) & 342 & 1.00 & 5.00 & 2.1 & 1.4 \\
\hline
\end{tabular}

Source: Field Survey, 2019.

From the descriptive statistics in Table 3, the respondents were generally dissatisfied with their promotions, ranking, rewards and equity. This is an indication that reward in the Ghana Education Service were generally perceived by staff as hardly satisfactory. Simply put, work in the GES is not adequately rewarding.

\subsection{Effect of Promotion on Teacher Performance}

Even though satisfaction levels with the promotion process in GES and subsequent rewards were generally low, its influence on teacher performance was quite good. From Table 4, the impact of promotion on a lesson note preparation scored a mean of 3.2 with a standard deviation of 1.2. Similar results were obtained for impact of promotion on teacher regularity in class, punctuality to class and setting and marking of class exercises. These were indications that promotion was linked to performance. So, once teachers exhibit a certain performance they would expect a certain result when it comes to promotion. This also implies that the expectancy theory is at play here.

Table 4. Effect of promotion on teacher performance

\begin{tabular}{|c|c|c|c|c|c|}
\hline Variables & $\mathrm{N}$ & Min. & Max. & Mean & SD. \\
\hline To what extent does lesson notes preparation determine your promotion success? & 342 & 1.00 & 5.00 & 3.2 & 1.2 \\
\hline To what extent does your regularity in class influence your promotion? & 342 & 1.00 & 5.00 & 3.4 & 1.1 \\
\hline To what extent does punctuality to class affect your chances of getting promoted? & 342 & 1.00 & 5.00 & 3.3 & 1.3 \\
\hline $\begin{array}{l}\text { To what extent do the setting and marking of class exercises determine your success in } \\
\text { promotion? }\end{array}$ & 342 & 1.00 & 5.00 & 3.2 & $\overline{1.2}$ \\
\hline
\end{tabular}

Source: Field Survey, 2019

\subsection{Impact of Promotion on Retention of Teachers}

When they were asked whether promotion in the GES would retain them on the job, $51.5 \%$ of the respondents answered in the affirmative compared to $48.5 \%$ who thought otherwise. This meant that close to half of GES staff would leave their jobs for other sectors which they consider more rewarding even if they were promoted. This also confirms the descriptive 
statistics in Table 3, that respondents were generally indifferent or dissatisfied with promotions and issues of internal and external equity.

Table 5. Impact of promotion on retention of teachers

\begin{tabular}{lcc}
\hline Response & Frequency & Percent \\
\hline Yes & 176 & 51.5 \\
No & 166 & 48.5 \\
\hline Total & 342 & 100.0 \\
\hline
\end{tabular}

Source: Field Survey, 2019.

\subsection{Perception of Fairness in the Promotion Process}

As indicated in Table 3, majority of respondents felt that the promotion process was basically unfair on the basis that questions asked at interviews were not relevant to their profession. Moreover, they claimed there was high level of subjectivity in the process in the form of favouritism thereby making the whole promotion process less objective and inimical to competence and ability. Some stated clearly that some circuit supervisors, heads of schools and educational administrators had their favourites who in turn take unequal advantage of the promotion process. Others even part with sums of monies and other gifts especially to circuit supervisors who come around for inspection. This underscores the reason why the average rating in the survey was 2.5 , indicating low for perception of fairness in the promotion process.

\subsection{Satisfaction with Promotion Outcomes}

Most teachers indicated that they were not satisfied with the promotion outcomes thus confirming the results in Table 3 . Numerous reasons were advanced to this effect. To them the number of years spent on a rank before going on promotion was too long a time. Some took five years and others six years to get promoted instead of the three to four years they were told. In addition, the salary increases and other rewards were too meager as compared with other public sector workers. In an effort to find out some of the rewards attached to promotion, it was found out that salary adjustment to higher levels as well as appointment to higher responsibility positions in the service were the main rewards.

\subsection{Equity}

Even though there was general dissatisfaction with the promotion outcomes, majority of teachers claimed that there was fairness regarding reward distribution. Once a teacher was promoted, his or her salary was equal to others of same rank and level within the Ghana Education Service. However, compared with other public sector workers, they noticed differences whereby employees of the Ghana Education Service were the worse off.

\subsection{Correlation Analysis}

\subsubsection{Fairness and Satisfaction with Promotion Outcomes}

Correlation analysis involving Pearson $r$ was performed to find out if any relationship existed between perceived fairness in the promotion process and satisfaction with rank on one hand and satisfaction with rewards on the other. The results show that there is a positive moderate correlation between perceived fair promotion process and satisfaction with rank $(\mathrm{r}=.34, a=.01$, p-value $=.000)$. Similarly, there is significant positive correlation between fairness in the promotion process and teachers' satisfaction with rewards $(\mathrm{r}=.21, a=.01$, $\mathrm{p}$-value $=.000)$. However, this relationship is weak. Putting it together, the results of the correlation tests show that perception of fairness in the promotion process enhances satisfaction with both ranks and rewards given to teachers.

Table 6. Correlation between perceived fairness and promotion outcomes

\begin{tabular}{llcccc}
\hline Pearson Correlation $(\boldsymbol{r})$ & Fairness & Rank & Rewards \\
\hline \multirow{2}{*}{ Fairness } & Correlation Coefficient & 1.000 & $.339^{* *}$ & $.205^{* *}$ \\
\cline { 2 - 6 } & Sig. (2-tailed) &. & .000 & .000 \\
\cline { 2 - 6 } & $\mathrm{N}$ & 342 & 342 & 342 \\
\hline
\end{tabular}

**Correlation is significant at .01 level (2-tailed)

Source: Field Survey, 2019.

\subsubsection{Satisfaction with Rank and Effective Teaching}

One of the specific objectives of the study was to determine the relationship between satisfaction with promotion 
outcomes and effective teaching. By promotion outcomes, the study meant ranks associated with promotions and accompanying rewards or benefits received after successful promotion. These may include salary raise, increased autonomy and responsibility.

Effective teaching on the other hand was operationalized to include four variables namely; lesson notes preparation, regularity in class, punctuality to class and giving and marking class exercises. A Pearson correlation was conducted to see how satisfaction with the promotion outcomes correlates with participation in effective teaching. The results show that there was significant positive correlation between the two variables, that is satisfaction with promotion outcomes and effective teaching, but generally moderate and weak. For instance, satisfaction with rank positively correlates moderately with lesson notes preparation $(\mathrm{r}=.28, \mathrm{a}=, 01, \mathrm{p}$-value $=.000)$, teachers' regular attendance to class $(\mathrm{r}=.28, \mathrm{a}=.01, \mathrm{p}$-value $=.000)$ and giving and marking class exercises $(\mathrm{r}=.21, \mathrm{a}=.01, \mathrm{p}$-value $=.000)$. There is, however, a weak correlation between satisfaction with rank and punctuality to class by teachers $(\mathrm{r}=.13, \mathrm{a}=.05$, $\mathrm{p}$-value $=.017)$.

Table 7. Correlation between satisfaction with rank and effective teaching

\begin{tabular}{llrrrrrr}
\hline Pearson Correlation $(\mathrm{r})$ & \multicolumn{2}{c}{ Rank } & Lesson Notes & Regularity & Punctuality & Exercises \\
\hline \multirow{2}{*}{ Ranks } & Correlation Coefficient & 1.000 & $.225^{* *}$ & $.274^{* *}$ & $.118^{* *}$ & $.208^{* *}$ \\
\cline { 2 - 9 } & Sig. (2-tailed) &. & .000 & .000 & .029 & .000 \\
\cline { 2 - 9 } & $\mathrm{N}$ & 342 & 342 & 342 & 342 & 342 \\
\hline
\end{tabular}

**Correlation is significant at .01 level (2-tailed)

*Correlation is significant at .05 level (2-tailed)

\subsubsection{Satisfaction with Rewards and Effectiveness in Teaching}

Though also significantly positive, satisfaction with rewards generally correlated very weak with the factors serving as parameters of effective teaching. Simply put, whereas satisfaction with rewards correlates weakly with lesson notes preparation $(\mathrm{r}=.15)$, teacher regularity in class $(\mathrm{r}=.15$ and punctuality $(\mathrm{r}=.18)$ at $\mathrm{a}=.01$, giving and marking of class work correlated weakly at $\mathrm{a}=.05$.

Table 8. Correlation between satisfaction with rewards and effective teaching

\begin{tabular}{llcccccc}
\hline Pearson Correlation $(\mathrm{r})$ & Rewards & Lesson Notes & Regularity & Punctuality & Exercises \\
\hline \multirow{2}{*}{ Rewards } & Correlation Coefficient & 1.000 & $.112^{*}$ & $.133^{*}$ & $.137^{* *}$ & $.118^{*}$ \\
\cline { 2 - 8 } & Sig. (2-tailed) &. & .039 & .014 & .011 & .029 \\
\cline { 2 - 8 } & $\mathrm{N}$ & 342 & 342 & 342 & 342 & 342 \\
\hline
\end{tabular}

*Correlation is significant at the .05 level (2-tailed)

\subsubsection{Fairness and Effectiveness in Teaching}

This study again sought to find out how perception of fairness in the promotion process correlates with effective teaching whereby effective teaching was operationalized to include lesson notes preparation, regularity in class, punctuality to school and giving and marking of assignments. Results of Pearson correlation show that there is significant positive correlation between perception of fairness in the process and effective teaching. Specifically, fairness correlates moderately with three aspects of effective teaching namely lesson notes preparation $(r=.21 ; \mathrm{p}<.01)$, teacher regularity in class $(r=.26 ; \mathrm{p}<.01)$, giving and marking of assignments $(r=.20 ; \mathrm{p}<.01)$.

Table 9. Correlation between perceived fairness and effective teaching

\begin{tabular}{llcccccc}
\hline Pearson Correlation $(\mathrm{r})$ & Fairness & Lesson Notes & Regularity & Punctuality & Exercises \\
\hline \multirow{2}{*}{ Fairness } & Correlation Coefficient & 1.000 & $.226^{* *}$ & $.260^{* *}$ & $.189^{* *}$ & $.202^{* *}$ \\
\cline { 2 - 8 } & Sig. (2-tailed) &. & .000 & .000 & .000 & .000 \\
\cline { 2 - 8 } & $\mathrm{N}$ & 342 & 342 & 342 & 342 & 342 \\
\hline
\end{tabular}

**Correlation is significant at .01 level (2-tailed) 


\subsection{Relationship between Promotion and Teacher Attrition}

To explore the relationship among the various variables examined by the study, the binary logistic regression was conducted. The dependent variable was teacher attrition within Ghana Education Service. This was recoded as $1=$ Yes, showing the presence of attrition and $0=$ No, also showing the absence of attrition i.e. retention. The independent variables included promotion, fairness of the promotion process, satisfaction with rank, satisfaction with rewards, internal equity and external equity. All of the independent variables were measured using ordinal scale.

From Table 6, the Omnibus Test of Model Coefficient shows how the set of predictor variables performed in the model. In other words, the "goodness of fit" test is performed to determine the significance of the variables as predictors of teachers' retention/attrition in the Ghana Education Service. In this case, the p-value is 0.000 which means $p<0.05$, an indication that the set of variables is statistically good enough (significant) in determining teacher retention/attrition. The chi squares value is 56.026 at 6 degrees of freedom.

Block 1: Method =

Table 10. Omnibus Tests of Model Coefficients

\begin{tabular}{llccrr}
\hline & & Chi-square & Df & Sig. \\
\hline Step 1 & Step & 56.027 & 6 & .000 & .000 \\
\cline { 2 - 6 } & Block & 56.027 & 6 & .000 \\
\cline { 2 - 6 } & Model & 56.027 & 6 & 600 \\
\hline
\end{tabular}

Source: Field survey, 2019.

To further enhance the "goodness of fit" test above, the Hosmer and Lemeshow Test was also conducted using SPSS to support the model. Unlike the Omnibus Tests of model coefficients which requires a significance less than 0.05 , the Hosmer-Lemeshow Goodness of Fit Test requires a value greater than 0.05 . In this case, the p-value is 0.204 with a Chi-square value of 10.958 at 8 degrees of freedom. This shows that $p>0.05$, indicating support for the model as a good set of predictor variables regarding teacher attrition.

Table 11. Hosmer and Lemeshow Test

\begin{tabular}{lccc}
\hline Step & Chi-square & Df & Sig. \\
\hline 1 & 10.958 & 8 & .204 \\
\hline
\end{tabular}

Source: Field survey, 2019.

In Table 12 (model summary) the Cox \& Snell R Square and the Nagelkerke R Square values show the amount of variation in the dependent variable explained by the model (from the minimum value of 0 indicating no relationship to a maximum value of 1 indicating perfect relationship). In this case the two values are 0.216 and 0.288 , an indication that between $21.6 \%$ and $28.8 \%$ of teacher attrition is explained by the set of predictor variables in the model.

Table 12. Model Summary

\begin{tabular}{lccc}
\hline Step & -2 Log likelihood & Cox \& Snell R Square & Nagelkerke R Square \\
\hline 1 & $262.542^{\mathrm{a}}$ & .216 & .288 \\
\hline
\end{tabular}

a. Estimation terminated at iteration number 4 because parameter estimates changed by less than .001 .

Source: Field survey, 2019.

Furthermore, the classification Table $(\alpha)$ shows the percentage of accuracy of the model in explaining the relationship between the dependent variable - teacher attrition and the set of predictor variables - promotion, fairness of the promotion process, rewards, rank, internal equity, and external equity. The overall percentages on the table show that $73.5 \%$ of the teacher population is classified as having characteristics of the model.

To establish the contribution of the individual variables as predictors of attrition, the Variables in the Equation Table present the Wald Test Scores among others. From Table 8, internal equity is the highest contributor to the model with 27.49 , followed by fairness (9.23) and external equity (7.75). These three variables are also the significant predictors to 
the model since the significant values are less than .05 .

Table 13. Variables in the Equation

\begin{tabular}{|c|c|c|c|c|c|c|c|c|c|}
\hline & \multirow[b]{2}{*}{ Variables } & \multirow[b]{2}{*}{$\mathrm{B}$} & \multirow[b]{2}{*}{ S.E. } & \multirow[b]{2}{*}{ Wald } & \multirow[b]{2}{*}{ Df } & \multirow[b]{2}{*}{ Sig. } & \multirow[b]{2}{*}{$\operatorname{Exp}(B)$} & \multicolumn{2}{|c|}{ 95.0\% C.I.for $\mathrm{EXP}(\mathrm{B})$} \\
\hline & & & & & & & & Lower & Upper \\
\hline \multirow[t]{7}{*}{ Step $1^{\mathrm{a}}$} & Promotion (1) & .626 & .381 & 2.697 & 1 & .101 & 1.870 & .886 & 3.945 \\
\hline & Fairness & -.443 & .146 & 9.239 & 1 & .002 & .642 & .482 & .854 \\
\hline & Rank & .007 & .193 & .001 & 1 & .970 & 1.007 & .690 & 1.472 \\
\hline & Rewards & -.255 & .177 & 2.070 & 1 & .150 & .775 & .548 & 1.097 \\
\hline & Internal & .724 & .138 & 27.499 & 1 & .000 & 2.063 & 1.574 & 2.705 \\
\hline & External & -.359 & .129 & 7.748 & 1 & .005 & .699 & .543 & .899 \\
\hline & Constant & -.098 & .562 & .031 & 1 & .861 & .906 & & \\
\hline
\end{tabular}

a. Variable(s) entered on step 1: promotion, Fairness, Rank, Rewards, Inter, Exter.

Source: Field survey, 2019.

Three other variables did not significantly contribute to the model, namely promotion, rank and rewards. These have significant value less than 0.05 . The $\mathrm{B}$ values on the table represent the strength and the direction of the relationship between the dependent variable (attrition) and independent variables (predictors). A negative B is an indication that an increase in the independent variable will result in a decrease in the dependent variables. Hence, improvement in fairness of the promotion process will reduce teacher attrition as a problem between $48.2 \%(0.482)$ and $85.4 \%(0.854)$ in the actual teacher population. In short, there is a strong negative correlation between fairness of promotion process and teacher attrition in the Ghana Education Service.

The higher the fairness, the lower the attrition and therefore, better retention. With regard to external equity, the paper again identifies a significant negative correlation between teacher attrition and external equity (B value $=-0.359$ ). This also means that improvement in the working condition in GES towards those of their counterparts in other public sectors will lead to reduction in teacher attrition by between $69.9 \%$ and $95 \%$. In other words, $69.9 \%$ of teachers would be retained in GES every time working conditions are improved towards making it equivalent to other public sectors workers. This percentage $(69.9 \%)$, however will fall within a range of $54.3 \%$ to $89.9 \%(0.543$ and 0.899$)$ in the actual teacher population.

\section{Discussion}

From the analysis, it was clear that the non-professional teachers popularly known as pupil teachers were engaged by the Ghana Education. This presupposes that numbers of professional teachers are not adequate either because the number of trained persons is not sufficient or trained teachers are leaving the teaching field or both thus, causing the enrolment of non-professional teachers to fill the gap. The analysis again showed that non-professional teachers never go for promotion as spelt out in the Ghana Education Service. This means that the Service, in principle, has no career development path for pupil teachers (Quan-Baffour and Arko-Achemfuor, 2014). What then will be the source of motivation and drive to continuously put in one's best performance as a pupil teacher? The only reason a pupil teacher will work hard is to receive pay. However, motivation to stay in the organization will be lacking since there is no path for career development. The lack of growth for pupil teachers can be a source for mediocrity which will in the long run affect the performance of pupils and students (Wong, 2009). It is, however, pertinent to note that there are opportunities for pupil teachers to do distance education to obtain diploma which will then enable them climb up the promotional ladder. Such an opportunity remains the only avenue for possible career development by pupil teachers who can afford to pay for the cost of distance education.

Some other teachers, though in the minority, perceived the promotion process as too cumbersome compared to the outcome. This is where the third assumption of the expectancy theory lays a key role in explaining why some teachers remain unperturbed about promotion. The outcome is perceived to be low and unattractive given the hurdles to clear in order to arrive at such an outcome. In other words, the ranks and rewards (outcome) are not attractive or valuable (valence) and hence the promotion means nothing to them. For that matter, they prefer not to start any processes for promotion. It means that such teachers are already demotivated and would join the next available bus exiting the teaching field at the least opportunity. In other words, they have joined the bandwagon of non-professional teachers and could also condone mediocrity since they are not interested in any promotion. The criteria for promotion, in terms of performance and behaviour, are irrelevant to this category of teachers. Even though one would not recommend for the GES to relax the 
promotion process to accommodate such teachers, it would be prudent for the Service to improve upon the rewards following a successful promotion to make it attractive to all teachers to want to achieve by working hard. This is consistent with the expectancy theory which suggest that teachers exhibit a particular behaviour (thus hardworking) in order to achieve a specific primary result (good student achievements) which in turn results in a secondary outcome (in this case promotion to a higher rank in the teaching profession) making the teaching profession more attractive to the teachers (NěmeČková, 2017).

One other problem identified by the study regarding the promotion process in the Ghana Education Service was unfairness in the promotion process. Responses from the open-ended questions revealed that some teachers are promoted based on considerations outside the formal promotion criteria. The officers in charge of promotion have their favourites, so to say, who do not need to labour to meet the requirements for promotion. This therefore, serves as demotivation for hard working teachers who are 'not known' by anyone in the top hierarchy of the organizational ladder. Thus, such an instance is considered by the equity theory as causing distress among hard working teachers. This is because their colleagues who are in the good books of supervisors and heads of schools will put in less (effort) and get more (output). This makes the output-input ratio unequal when compared with the other. Demotivation to work first of all sets in and teachers may reduce their effort. In the case, where there are alternative job openings such teachers will leave the GES (attrition).

As a result of the teachers experiencing such unequal treatment based on differential affiliation with the top hierarchy officials of the Ghana Education Service, it demotivates other teachers who are striving hard through their performance to get promoted but are not being given the recognition and opportunity (Chiat and Panatik, 2019); (Alshallah, 2004); Almaaitah, Harada, Sakdan \& Almaaitah, 2017). This can really cause attrition of teachers (Geiger and Pivovarova, 2018) who do not benefit from such acts of favouritism.

In terms of rewards, the study confirmed what is seemingly common knowledge in Ghana that teachers in the GES are poorly rewarded (Osei Akuoko, Dwumah and Mahama Baba, 2012) compared with other public sector workers. This also means that there is external inequity which gives other sectors a comparative advantage over the GES and hence leads to teacher attrition at the next opportunity. So many teachers are, therefore, in the GES because of lack of they cannot find opportunities elsewhere. That is to say, people become teachers not by choice. This finding share semblance with the assertion that opportunities available to an individual are among the core motives that influence one's involvement in the teaching profession (Bergmark et al., 2018) as a means to survive economically. There is, therefore, no commitment.

With regard to internal equity, however, it was heartwarming to note that most teachers viewed it as fair. Once one was promoted to a particular rank, the benefits that go with that rank were equally distributed especially in terms of salary. This is because salaries and ranks are mechanized. However, satisfaction with the ranks and rewards were barely adequate. In other words, valence was low. Titles and rewards do not carry weight. They are merely decorative and probably only useful among in-group members but fall short when compared to homologous ranks in other sectors. Per the equity theory, employees become satisfied with their jobs when they feel the benefits or rewards obtained from the teaching profession is fair since it is commensurate to their efforts (Hatfield, Salmon and Rapson, 2011) (Watson et al., 2006). Thus, in this case where teachers were barely satisfied with the ranks and rewards, it could result in attrition from the teaching profession.

Self-rated responses showed positive impact of promotion on teacher performance in four areas, namely punctuality to school and class, regularity to school and class, lesson notes preparation and setting and marking exercises. This implies that promotion in the Ghana Education Service was tied to performance or at least, recommendations for promotion by supervisors was based on supervisee's performance thus, satisfying the conditions of expectancy theory (Vroom, 1964) .This means that employee capabilities, skills, behaviours and experiences are rewarded with promotion (instrumentality). However, close to half of the respondents still go reading 'want ads' even after they have been promoted. It is because the outcomes are not valuable. This shows that currently, promotion in the service is inconsequential to commitment and attrition. Whether one was promoted or not, it does not lead to commitment to stay within the service. This also confirms the fact that the outcomes or rewards following promotions were not satisfying (Yussif A. Aziz, 2013).

The above, again, confirms the result of the logistic regression test which shows that promotion was not a significant predictor of teacher attrition or retention in the Ghana Education Service. This finding is inconsistent with studies by (Horwitz, Heng and Quazi, 2003; Arnold, 2005; Rolfe, 2005); who found that the decision by most employees to stay in an organization is dependent on career development which includes opportunities for promotion and complementary benefits such as salary raise, autonomy, responsibility and recognition. This could be due to the fact that regardless of the promotion structure or system not being a significant predictor of teacher retention in the GES, the teachers actively engage in thoughtful deliberations and decisions considering the difficulty in finding alternative and lucrative employment opportunities, thereby accounting for their failure to exit the profession, 
Internal equity, fairness of the promotion process and external equity were significant predictors of teacher attrition in the service in that order. The findings further find support for the equity theory, which assumes that employees (here in teachers), evaluate the processes through which they obtain promotion in relation to their efforts and that of others to determine whether they have been treated equitably. This, in turn, influences their satisfaction with the process and consequently the outcome. Once they are dissatisfied they tend to vacate the teaching profession (Hatfield et al., 2011; Asni \& Sulong, 2018) depending on the availability of job opportunities in the other sectors. The findings further corroborates that of (Sitati, Were and Waititu, 2016) who established in their study that when job promotion is not done on a fair and equitable basis, employees are more likely to leave whilst a fair and equitable distribution of promotion results in employee retention.

\section{Conclusion}

The study concludes that the promotion process in the Ghana Education Service is tainted with favoritism which makes it less of a merit-based mechanism of advancing the course of excellence. The philosophy of 'who you know' and 'who knows you' discourages hard work among some teachers who are merely holding on while searching for better places to go. They are not in the profession to grow but it has become a transit point from where they will hop to other sectors. The study again reveals that the promotion process has consequences for teacher attrition and retention in the Ghana Education Service. In other words, a fair process enhances retention and an unfair process results in attrition or apathy whereby some teachers just ignore the promotion process and stay while looking for study leave to pursue higher education after which they will better their chances beyond the GES. Furthermore, this paper concludes that a merit-based promotion leads to satisfaction with outcomes namely rank and rewards and that satisfaction with rank and rewards also correlate significantly with effective teaching in the classroom whereby effective teaching means punctuality, regularity, prior preparation (lesson notes/planning) and giving and marking of assignments. Finally, the study further validates the assumptions of the two process theories used as theoretical framework. With regard to the expectancy theory, the findings in the study demonstrate that people join the GES as an organization with certain expectations. They hope that through a certain level of performance their expectations would be met thereby satisfying some personal needs. When those expectations are not met or they are met but their personal needs remain unsatisfied, they are likely to quit the Service. This is likely the situation of teachers who are extrinsically motivated. Hence, promotion per se does not ensure their retention since their needs are not satisfied. The outcomes (rank and rewards) are not valuable to them. On the other hand, the equity theory succeeds in explaining why fairness in the process retains teachers. This is also likely the situation of teachers who are intrinsically motivated. After comparing their input-outcome ratio with referent others, if they feel treated equitably, they are motivated not only to stay but to also participate effectively in teaching.

\section{Acknowledgement}

The authors are grateful to the Ejisu-Juaben Municipal Directorate for their voluntarism in giving secondary information on educational institutions and personnel. We equally thank them for their consent (verbal) to conduct the study using teachers in the municipality as research participants. Profound gratitude is extended to the teachers and headteachers for their respective roles in making the data collection process for this study a success.

\section{References}

Adam, A., \& Boakye, K. O. (2016). The Process of Staff Promotion in Relation to Salary or Wages Upgrade in the Public Sector Institutions : Local Government Service VS Ghana Education The Process of Staff Promotion in Relation to Salary or Wages Upgrade in the Public Sector Institutions. International Journal of Business and Management, 11(7), 245-280. https://doi.org/10.5539/ijbm.v11n7p245

Adams, J. S. (1963). Toward an understanding of inequity. Journal of Abnormal and Social Psychology, 67, 422-436. https://doi.org/10.1037/h0040968

Adams, J. S. (1965). Inequity in social exchange. Advances in experimental social psychology, 2, 267-299. https://doi.org/10.1016/S0065-2601(08)60108-2

Alshallah, S. (2004). Job satisfaction and motivation: how do we inspire employees? Radiology Management, 26(2), 47-51.

Al-zawahreh, A., \& Madi, F. A. (2012). The Utility of Equity Theory in Enhancing Organizational Effectiveness. European Journal of Economics, Finance and Administrative Sciences, 46.

Arnold, E. (2005). Managing human resources to improve employee retention. The Health Care Manager, 24(2), 132-140. https://doi.org/10.1097/00126450-200504000-00006

Asare, K. B, \& Nti, S. K. (2014). Teacher Education in Ghana : A Contemporary Synopsis and Matters Arising. SAGE Open, 1-8. https://doi.org/10.1177/2158244014529781 
Asare-Danso, S. (2014). Effects of Educational Policies on Teacher Education in Ghana: A Historical Study of the Presbyterian College of Education University of Cape Coast. International Journal of Humanities and Social Science, 4(6), 57-65.

Asni, F. A. H. M., \& Sulong, J. (2018). The Model of Istinbat by the Shariah Advisory Council of Central Bank of Malaysia. International Journal of Academic Research in Business and Social Sciences, 8(1), 218-248. https://doi.org/10.6007/IJARBSS/v8-i1/3778

Benneh, G. (2001). Education and Development: Challenges for 21st Century. Accra.

Bergmark, U. et al. (2018). Why become a teacher? Student teachers' perceptions of the teaching profession and motives for career choice. European Journal of Teacher Education, 41(3), 266-281. https://doi.org/10.1080/02619768.2018.1448784

Boomer Authority. (2010). Competitive strategies for a world class workforce: Why older workers matter in Oregon?

Brown, C. K., Donkoh, S., \& Eyiah-Wilson, K. (2013). Retention of administrative staff of the Ghana Education Service in the Northern Region of Ghana. Educational Research, 4(February), 163-173.

Chiat, L. C., \& Panatik, S. A. (2019). Perceptions of Employee Turnover Intention by Herzberg's Motivation-Hygiene Theory: A Systematic Literature Review. Journal of Research in Psychology, 1(2), 10-15. https://doi.org/10.31580/jrp.v1i2.949

Chris, D. S. (2009). Promotions as motivation factor towards emloyees' performance: A case study of Uganda Police Forces (UPF) (1995-2005). Makerere University.

Danku, L. S. et al. (2015). Performance Appraisal in the Ghana Education Service, the Case of Basic School Teachers in Ho Municipality. International Journal of Managerial Studies and Research, 3(6), 117-133.

Department for International Development. (2003) Teacher Training in Ghana - Does it Count? Country Report One, Sussex.

Derek, O. A. C. (2015). 'Universal Sustainable Development goals; Understanding the Transformational Challenge for Developed Countries; Report of a Study by Stakeholder Forum.

Education International. (2015). The status of teachers and the teaching profession A study of educational unions perspectives, Education International Research Institute. 5 Boulevard deu Roi Albert II, Brussels, Belgium.

Frank, S. A., \& Lewis, G. B. (2004). Government employees: Working hard or hardly working? American Review of Public Administration, 34, 36-51. https://doi.org/10.1177/0275074003258823

Geiger, T., \& Pivovarova, M. (2018). The effects of working conditions on teacher retention. Teachers and Teaching, 24(6), 604-625. https://doi.org/10.1080/13540602.2018.1457524

Ghana Education Service. (2016). Municipal Education Directorate. Ejisu-Juabeng.

Government of Ghana. (2008). The Ghana Education Act,2008.

Hatfield, E., Salmon, M., \& Rapson, R. L. (2011). Equity theory and social justice. Journal of Management, Spirituality \& Religion, 8(2), 101-121. https://doi.org/10.1080/14766086.2011.581818

Horwitz, F. M., Heng, C. T., \& Quazi, H. A. (2003). Finders, keepers? Attracting, motivating and retaining knowledge workers. Human Resource Management Journal, 13(4), 23-44. https://doi.org/10.1111/j.1748-8583.2003.tb00103.x

Huseman, R. C., Hatfield, J. D., \& Miles, E. W. (1987). A new perspective on equity theory: The equity sensitivity construct. Academy of Management Journal, 12, 222-234. https://doi.org/10.5465/amr.1987.4307799

Kombat, D. K. (2017) Assessing Staff Promotion of Public Sector Emloyees in Ghana : A Case Study of the Accra Metro Education Directorate. University of Ghana.

Kossivi, B., Xu, M., \& Kalgora, B. (2016). Study on Determining Factors of Employee Retention. Open Journal of Social Sciences, 4(May), 261-268. https://doi.org/10.4236/jss.2016.45029

Kunyiha, E. et al. (2016). Infuence of teachers service commission human resource management practices on teachers committment in public secondary school in Tetu Sub Country,Nyeri. International Journal of Business, Social Sciences \& Education, 2(1), 1-16.

Lambright, K. (2010). An Update of a Classic: Applying Expectancy Theory to Understand Contracted Provider Motivation. Administration and Society, (July 2010). https://doi.org/10.1177/0095399710362714

Lunenburg, F. C. (2011). Expectancy Theory of Motivation : Motivating by Altering Expectations. International Journal of Management, Business and Administration, 15(1), 1-6. 
Miaoulis, G., \& Michener, D. (1976). An Introduction to Sampling. Kendall/Hunt Publishing Company.

Mobley, W. H., \& Meglino, B. M. (1977). A behavioral choice model of budget allocation behavior of academic deans. Academy of Management Journal, 20, 564-572. https://doi.org/10.2307/255357

Monge, P. R., Cozzens, M. D., \& Contractor, N. S. (1992). Communication and motivational predictors of the dynamics of organizational innovation', Organizational Science, 3, 250-274. https://doi.org/10.1287/orsc.3.2.250

Mugweru, W. (2013). Promotion of secondary school teachers by gender, experience and school type , a case in Kenya. Middle Eastern \& African Journal of Educational Research, 6, 24-43.

Mustapha, N., \& Zakaria, Z. C. (2013). The Effect of Promotion Opportunity in Influencing Job Satisfaction among Academics in Higher Public Institutions in Malaysia. International Journal of Academic Research in Business and Social Sciences, 3(3), 20-26.

National Development Planning Commission, Ghana. (2015). Ghana and the Sustainable Development Goals (SDGs).

NěmeČková, I. (2017). The role of benefits in employee motivation and retention in the financial sector of the czech republic. Economic Research-Ekonomska Istrazivanja . Routledge, 30(1), 694-704. https://doi.org/10.1080/1331677X.2017.1314827

OECD. (2011). Teachers Matter: Attracting, Developing and Retaining Effective Teachers. Directorate for Education, Education and Training Policy Division, 50(September, 2011). https://doi.org/10.1787/9789264097650-en

Ogonda, F. O. et al. (2015). An analysis of work motivation and teacher job satisfaction in public secondary schools in Rarieda', Journal of Investment and Management 2015, 4(6), 377-390.

Osei Akuoko, K., Dwumah, P., \& Mahama Baba, W. (2012). Teacher Motivation and Quality Education Delivery: a Study of Public Basic Schools in Tamale Metropolis in Ghana. International Journal of Social Science \& Interdisciplinary Research, 1(12), 29-46. https://doi.org/10.1155/2012/479361

Owusu-Agyakwa, G., Ackah, S. K., \& Kwamena-Poh, M. (1993). The mother of our schools: A history of the Presbyterian Training College, Akropong-Akuapem, and biography of the principals (1848-1993). 'Accra.

Oyaro. K. (2010). Education in Kenya. Kenyan teachers flock foreign universities to improve chances of promotion. In Promotion of Secondary School Teachers by Gender, Experience and School Type; a Case in Kenya by W. Mugweru (2013). Kenyatta University, Dept. of Foundation Education, Nairobi Kenya.

Pergamit, M., \& Veum, J. R. (2016). What is a Promotion? ILR Review, 52(4), 581-601. https://doi.org/10.1177/001979399905200405

Quan-Baffour, K. P., \& Arko-Achemfuor, A. (2014). The Effects of a Lack of Career Pathing on Job Satisfaction Among South African Teachers. Africa Education Review, 11(1), 1-16. https://doi.org/10.1080/18146627.2013.853564

Rolfe, H. (2005). Building a stable workforce : Recruitment and retention in the child care and early years eector. Children \& Soiety, 19(April 2004), 54-65. https://doi.org/10.1002/chi.829

Sam, F., \& Effah, B. (2014). Exploring issues of teacher retention and attrition in Ghana : A case study of Public Senior High Schools in Kwabre East. Journal of Education and Practice, 5(1), 83-89.

Sambou, R. (2019). NAGRAT accuses GES of delaying promotions. Ghanaian Times. Retrieved August 2, 2019, from at https://www.ghanaiantimes.com.gh

Sinha, C. (2012). Factors affecting employee tetention: A comparative analysis of two organizations from heavy engineering industry. European Journal of Business and Management, 4(3), 145-163.

Sitati, N., Were, S., \& Waititu, G. A. (2016). Effect of Job Promotion on Employee Retention in Hotels in Kenya. The Strategic Journal of Business \& Change Management, 3(4), 956-972.

The Schwab Foundation. (2017). The schwab foundation for social entrepreneurship annual report.

Turnley, W. H., \& Feldman, D. C. (2000). Re-examining the e ects of psychological contract violations : unmet expectations and job dissatisfaction as mediators. Journal of Organizational Behavior, 42, 25-42. https://doi.org/10.1002/(SICI)1099-1379(200002)21:1<25::AID-JOB2>3.0.CO;2-Z

United States Agency for International Development. (2012). Scheme of Service : Ghana Education Service, 8(641), 1-68.

Vroom, V. (1964). Work and motivation. Pittsburgh: Wiley and Sons.

Wahba, M. A., \& House, R. J. (1974). Expectancy theory in work and motivation: Some logical and methodological issues. Human Relations, 27, 121-147. https://doi.org/10.1177/001872677402700202 
Watson, R. et al. (2006). The relationship between job satisfaction and managerial remuneration in small and medium-sized enterprises: an empirical test of "comparison income" and "equity theory" hypotheses. Applied Economics, 28(5), 567-576. https://doi.org/10.1080/00036849600000036

Wong, P. M. (2009). Teachers and Promotion: Research Evidence on the Role of Gender, Career Intentions, Promotion Criteria and Teacher Satisfaction. In Saha, L. J., \&Dworkin, A. G. (Eds.), International Handbook of Research on Teachers and Teaching. Boston, MA: Springer US (Springer International Handbooks of Education), pp. 511-523. https://doi.org/10.1007/978-0-387-73317-3_33

Yamane, T. (1967). Statistics: An Introductory Analysis. Second Edi. New York: Harper \& Row.

Yeboah, S. (2012). The Impact of Human Resource Management Practices on Teacher Retention in the Ghana Education Service: A Case Study of Schools in the Cape Coast Metropolis. Kwame Nkrumah University of Science and Technology.

Yussif A. A. (2013). Attrition and Retention of Teachers in the Public Senior High Schools in the Tamale Metropolis of Northern Region. University of Cape Coast.

\section{QUESTIONNAIRE FOR TEACHERS IN THE GHANA EDUCATION SERVICE PROMOTION OF TEACHERS IN THE GHANA EDUCATION SERVICE; A STUDY OF TEACHERS IN THE EJISU-JUABEN MUNICIPALITY}

Table 1. Background information of respondent

Instruction: Please, tick the number which corresponds to your choice in each case.

\begin{tabular}{|l|l|l|l|l|l|l|l|}
\hline Sex & Tick & Age & Tick & Academic Qualification & Tick & Professional Qualification & Tick \\
\hline Male & 1 & Below 30 & 1 & S.H.S & 1 & Trained & 1 \\
\hline Female & 2 & $30-39$ & 2 & Post-Secondary & 2 & Untrained & 2 \\
\hline & & $40-49$ & 3 & Diploma & 3 & & \\
\hline & & $50-59$ & 4 & First Degree & 4 & & \\
\hline & & $60+$ & 5 & Higher Degree & 5 & & \\
\hline
\end{tabular}

5. Have you gone on promotion before in your career as a teacher? (If Yes, skip to question 7)

1. Yes ( ) 2. No ( )

6. If your response is to Question 5 is No, provide reason(s).

7. In your opinion, how fair is the promotion processes for teachers in G.E.S ?
1. Very Unfair ( )
2. Unfair ( )
3. Neutral
4. Fair
) 5. Very Fair ( )

8. Give reasons for your response to question 7 .

Table 2. Level of satisfaction with promotion outcomes (rank and rewards)

\begin{tabular}{|l|l|l|l|}
\hline Rank & Tick & Rewards & Tick \\
\hline Very satisfied & 5 & Very satisfied & 5 \\
\hline Satisfied & 4 & Satisfied & 4 \\
\hline Neutral & 3 & Neutral & 3 \\
\hline Dissatisfied & 2 & Dissatisfied & 2 \\
\hline Very dissatisfied & 1 & Very dissatisfied & 1 \\
\hline
\end{tabular}

11. Explain your responses in Table 2

12. What are some of the rewards that are associated with promotion?

Table 3. Equity in the promotion outcomes

\begin{tabular}{|l|l|l|l|}
\hline Compared with colleagues in G.E.S & Tick & Compared with other public sector organisations & Tick \\
\hline Very fair & 5 & Very fair & 5 \\
\hline
\end{tabular}




\begin{tabular}{|l|l|l|l|}
\hline Fair & 4 & Fair & 4 \\
\hline Neutral & 3 & Neutral & 3 \\
\hline Unfair & 2 & Unfair & 2 \\
\hline Very Unfair & 1 & Very Unfair & 1 \\
\hline
\end{tabular}

15. Give reasons for your responses in Table 3

Table 4. Level of participation in effective teaching and learning

\begin{tabular}{|l|l|l|l|l|l|l|l|}
\hline $\begin{array}{l}\text { Lesson Notes } \\
\text { Preparation }\end{array}$ & Tick & $\begin{array}{l}\text { Teacher } \\
\text { Regularity in } \\
\text { Class }\end{array}$ & Tick & $\begin{array}{l}\text { Teacher Punctuality } \\
\text { to Class }\end{array}$ & Tick & $\begin{array}{l}\text { Setting } \\
\text { Marking of } \begin{array}{c}\text { and } \\
\text { Exercises }\end{array}\end{array}$ & $\begin{array}{l}\text { Tick } \\
\text { Vess }\end{array}$ \\
\hline Very high & 5 & Very high & 5 & Very high & 5 & Very high & 5 \\
\hline High & 4 & High & 4 & High & 4 & High & 4 \\
\hline Loderate & 3 & Moderate & 3 & Moderate & 3 & Moderate & 3 \\
\hline Very low & 2 & Low & 2 & Low & 2 & Low & 2 \\
\hline
\end{tabular}

20. In your opinion, is the promotion in GES motivating enough to retain you as a teacher?

1. Yes ( ) 2. No ( )

21. Give reasons for your answer above

THANK YOU

\section{Copyrights}

Copyright for this article is retained by the author(s), with first publication rights granted to the journal.

This is an open-access article distributed under the terms and conditions of the Creative Commons Attribution license which permits unrestricted use, distribution, and reproduction in any medium, provided the original work is properly cited. 